\title{
Host Cell Tropism and Adaptation of Blood-Stage Malaria Parasites: Challenges for Malaria Elimination
}

\author{
Caeul Lim, ${ }^{1,2}$ Selasi Dankwa, ${ }^{1,2}$ Aditya S. Paul, ${ }^{1}$ and Manoj T. Duraisingh ${ }^{1}$ \\ ${ }^{1}$ Harvard T.H. Chan School of Public Health, Boston, Massachusetts 02115 \\ Correspondence: mduraisi@hsph.harvard.edu
}

\begin{abstract}
Plasmodium falciparum and Plasmodium vivax account for most of the mortality and morbidity associated with malaria in humans. Research and control efforts have focused on infections caused by $P$. falciparum and $P$. vivax, but have neglected other malaria parasite species that infect humans. Additionally, many related malaria parasite species infect nonhuman primates (NHPs), and have the potential for transmission to humans. For malaria elimination, the varied and specific challenges of all of these Plasmodium species will need to be considered. Recent advances in molecular genetics and genomics have increased our knowledge of the prevalence and existing diversity of the human and NHP Plasmodium species. We are beginning to identify the extent of the reservoirs of each parasite species in humans and NHPs, revealing their origins as well as potential for adaptation in humans. Here, we focus on the red blood cell stage of human infection and the host cell tropism of each human Plasmodium species. Determinants of tropism are unique among malaria parasite species, presenting a complex challenge for malaria elimination.
\end{abstract}

M ore than $60 \%$ of known infectious organisms are zoonotic, and they account for $75 \%$ of emerging human diseases (Taylor et al. 2001; Jones et al. 2008). The predominant species of malaria parasites infecting humans, Plasmodium falciparum and Plasmodium vivax, are anthroponotic in human populations; however, these species also originated from a transmission event from African great apes to humans (Liu et al. 2010, 2014). In addition, four other malaria parasite species from the genus Plasmodium infect humans: Plasmodium malariae, Plasmodium ovale curtisi, Plasmodium ovale wallikeri, thought to be transmitted within humans, and Plasmodium knowlesi, a zoonosis of humans from macaque monkeys. All Plasmodium species are characterized by a complex life cycle with several stages of differentiation through its anopheline mosquito vector and the vertebrate host. In humans, following a primary stage of infection and multiplication in the liver, parasites are released into the bloodstream. The clinical symptoms of malaria are associated with the blood stage, when parasites proliferate asexually by invasion of red blood cells (RBCs), replication, egress from the infected cell, and reinvasion of an uninfected cell in a cyclical fashion. A subset of parasites can leave this asexual cycle to develop into sexual forms known as gametocytes, which are taken up by mosquitoes,

${ }^{2}$ These authors contributed equally to this work.

Editors: Dyann F. Wirth and Pedro L. Alonso

Additional Perspectives on Malaria: Biology in the Era of Eradication available at www.perspectivesinmedicine.org

Copyright (C) 2017 Cold Spring Harbor Laboratory Press; all rights reserved; doi: 10.1101/cshperspect.a025494

Cite this article as Cold Spring Harb Perspect Med 2017; 7:a025494 
C. Lim et al.

in which sexual recombination and development occur to form parasites that can be reintroduced into the host, completing the life cycle.

In contrast to Plasmodium species that infect lizards and birds, the host range for primate Plasmodium species was thought to be highly restricted with only rare instances of zoonotic transmission. Recently, however, this dogma of strict host tropism in nature has been challenged, particularly with the emergence of P. knowlesi in the human population. Restrictions to infection of the host can occur at many points throughout the life cycle of Plasmodium parasites. Because host and vector habitat and behavior are difficult to study in natural settings, host-cell tropism at the RBC invasion step has been the most studied at the molecular and cellular level. Furthermore, with advances in molecular genomic and genetic tools, we now have a greater understanding of parasite species diversity present also in animal host populations. This increased knowledge raises several questions and concerns as the research agenda shifts toward the eradication of malaria. How large and deep is the repertoire of existing Plasmodium species? Is the range of Plasmodium species to which humans are susceptible fully known? Is the zoonotic reservoir significant today as a means of transmission?

Here, we review the molecular determinants at the RBC invasion step that regulate host-cell tropism, discussing how these factors may influence the ability of Plasmodium parasites to breach species barriers and expand host range, impeding efforts to eliminate malaria.

\section{MOLECULAR MEDIATORS OF RBC INVASION AND TROPISM}

For successful RBC invasion, an extracellular Plasmodium parasite must initiate and execute a complex, well-ordered series of molecular interactions with the plasma membrane surface of the host cell. At each step of invasion, parasite proteins or invasion ligands bind to native receptors on the RBC surface or secreted parasite receptors (Cowman et al. 2012). The two superfamilies of Plasmodium invasion ligands that mediate the most specific interactions with receptors on the RBC surface, and therefore thought to be primary determinants of tropism, are the Duffy binding-protein ligand (DBL) family and the reticulocyte-binding protein homolog (RBL) family (Fig. 1) (Cowman and Crabb 2006; Tham et al. 2012; Wright and Rayner 2014; Paul et al. 2015).

The DBL invasion ligands all contain a well-characterized Duffy-binding-like receptor-binding domain, named for the founding members of this family-the $P$. vivax Duffybinding protein (PvDBP) (Wertheimer and Barnwell 1989) and the orthologous P. knowlesi Duffy-binding protein $\alpha(\operatorname{PkDBP} \alpha)$ (Haynes et al. 1988). The interaction of PvDBP or $\operatorname{PkDBP} \alpha$ with the RBC Duffy antigen receptor for chemokines (DARC) is the major determinant of human infection by these Plasmodium species (Miller et al. 1975; Singh et al. 2005). $P$. falciparum has an even larger repertoire of DBL invasion ligands, all of which use sialic acid-containing receptors on the human RBC surface to mediate invasion. At least one of these invasion ligands, PfEBA-175 has previously been implicated in host tropism (Martin et al. 2005).

The $P$. vivax proteins PvRBP1 and PvRBP2, for which the RBL family is named, are thought to restrict $P$. vivax to reticulocytes by virtue of their specific binding to reticulocytes (Galinski et al. 1992). Despite the kinship between the two species, the RBL ligands in P. knowlesi, $\mathrm{PkNBPXa}$ and $\mathrm{PkNBPXb}$, are strongly divergent from their $P$. vivax counterparts (Mayer et al. 2009); their role in human infection is not known. In $P$. falciparum, PfRh proteins have been shown to underlie preferences for specific receptor repertoires (PfRh4; Stubbs et al. 2005; Gaur et al. 2006), as well as preference of RBCs from different host species (Rh5; Hayton et al. 2008, 2013).

A more detailed review of factors involved in invasion of host RBCs by the parasites can be found in Singh and Chitnis (2016).

\section{Plasmodium knowlesi: AN ESTABLISHED ZOONOSIS}

\section{A Zoonosis Happening Today}

P. knowlesi is currently the only clearly zoonotic malaria parasite. Although the first natural case 

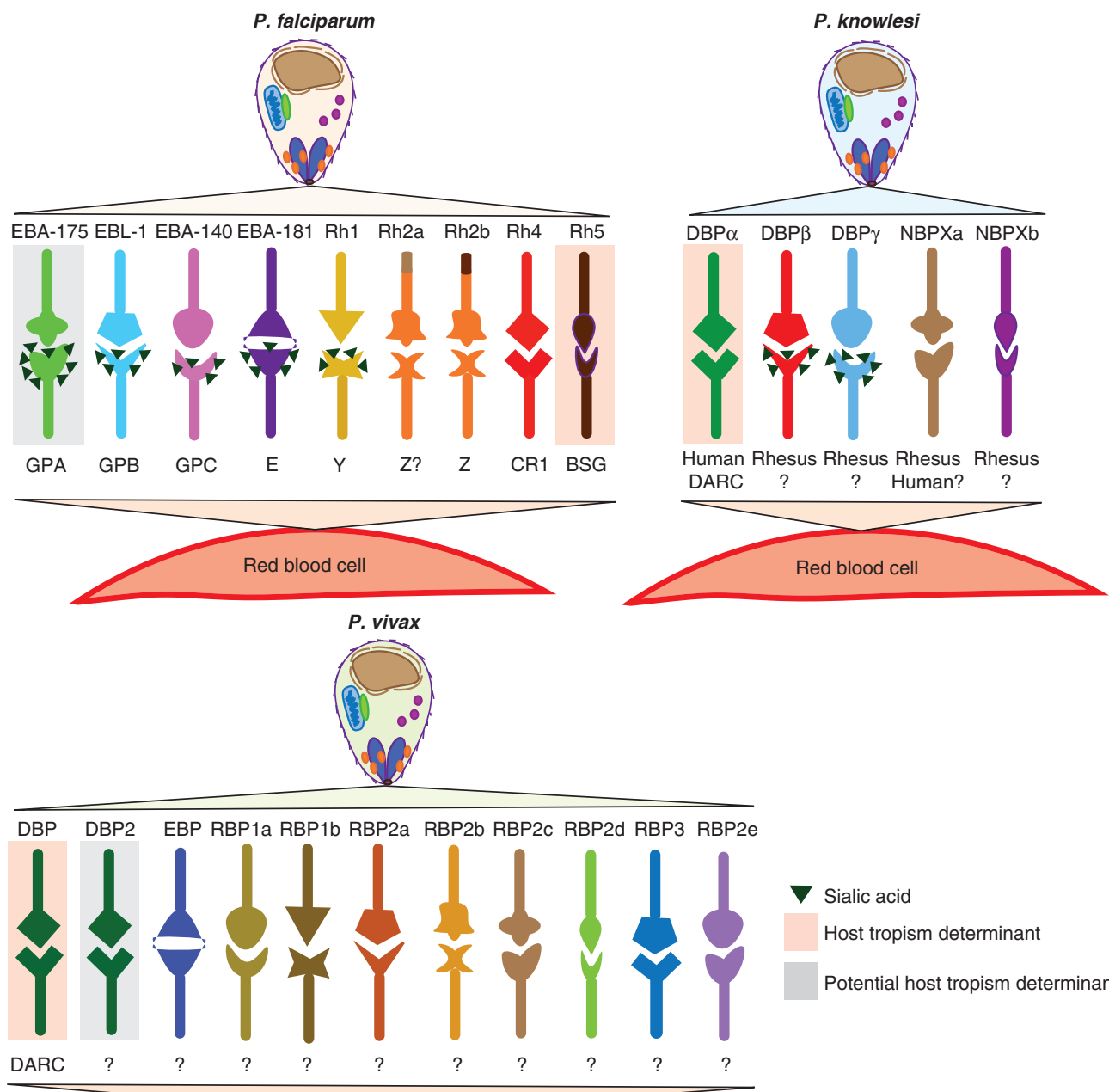

Sialic acid

Host tropism determinant

Potential host tropism determinant

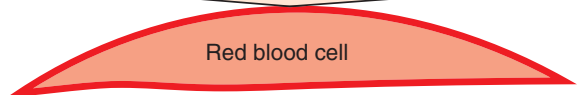

Figure 1. Specific ligand-receptor interactions mediate Plasmodium invasion of red blood cells (RBCs) that can determine host tropism. Parasite invasion ligands and their cognate RBC receptors are shown for Plasmodium falciparum, Plasmodium vivax, and Plasmodium knowlesi. A question mark or letter indicates receptors that are yet to be identified. Orange shading highlights known host tropism determinants, whereas grey shading indicates potential host tropism determinants. The triangles on some RBC receptors denote sialic acid residues. For $P$. vivax, DBP2 represents the duplicated DBP that has been implicated in P. vivax invasion of Duffy antigen receptor for chemokines (DARC)-negative individuals (Ménard et al. 2013). The expanded RBP family identified through whole-genome sequencing (WGS) of the P. vivax SalI reference strain (Carlton et al. 2008) comprises RBP1a, RBP1b, RBP2a, RBP2b, RBP2c, RBP2d, and RBP3, whereas EBP and RBP2e represent the predicted Duffy-binding protein ligand (DBL) and reticulocyte-binding protein homolog (RBL) orthologs identified through WGS of a P. vivax field isolate (Hester et al. 2013). P. knowlesi DBP $\alpha$-DARC invasion pathway functions in invasion of macaque RBCs; however, it does not appear to be a tropism determinant for the macaque host population. NBPXa has been shown to bind human RBCs in vitro, but its role in invasion of human RBCs remains to be defined. 
C. Lim et al.

of $P$. knowlesi malaria was reported as early as 1965 (Chin et al. 1965), it was only in 2004 that Singh et al. conclusively showed that the majority, if not all, of cases diagnosed as P. malariae on the basis of morphology in the Kapit division of Malaysia from 2000 to 2002 were in fact $P$. knowlesi (Singh et al. 2004). A follow-up study examined archival blood films from 1996 and confirmed that misdiagnosis of $P$. knowlesi for P. malariae had been common earlier than realized. The investigators also speculated that an earlier survey conducted in 1952 may also have misidentified $P$. knowlesi cases as $P$. malariae, challenging the idea that it is a newly emerging zoonosis (Lee et al. 2009). Since then, cases have been reported in various regions of Southeast Asia and P. knowlesi is now the leading cause of malaria in some parts of Malaysia (Singh and Daneshvar 2013). Although there is significant evidence suggesting that most transmission is zoonotic (Singh et al. 2004; Daneshvar et al. 2009), a recent study reports cases, albeit limited, of infection within families, without notable interaction with potential zoonotic hosts (Barber et al. 2012). Intriguingly, another recent study suggests that the prevalence may be higher than previously thought, with a potentially large asymptomatic population harboring the parasite (Fornace et al. 2015). In any case, human encroachment on macaque habitats (Cox Singh and Culleton 2015) will only increase the opportunity for the parasite to evolve and adapt to humans. To date, there is little evidence of direct transmission among humans (Singh et al. 2004; Daneshvar et al. 2009).

\section{P. knowlesi Diversity}

Considerable diversity has been found within P. knowlesi strains isolated in human populations. Parasitemia and disease severity in human patients were found to be associated with a specific allele of the $\mathrm{PkNBPXb}$ invasion ligand (Ahmed et al. 2014). A subsequent whole-genome study found dimorphism in the natural $P$. knowlesi population (Pinheiro et al. 2015). A larger study soon supported the possibility of two distinct $P$. knowlesi populations in circulation (Assefa et al. 2015; Divis et al. 2015). These studies, comprising isolates from two natural macaque hosts (long-tailed and pig-tailed macaques), as well as humans, showed that there are two distinct sympatric clusters of $P$. knowlesi matching to the two natural macaque hosts. The genetic diversity between these clusters was great enough to suspect subspeciation. Strikingly, although interaction between the clusters is likely limited because of different geographical and ecological niches of the macaque hosts, both of the clusters are found in humans. Introgression between subspecies provides opportunities for a parasite to adapt to a new environment and potentially new host organisms. The possibility of hybridization in the human host was speculated, based on genetic mosaicism observed across the genome. Further, through genomic analyses of human isolates several genes were found to be under strong positive selection in the human population. These data indicate the potential for P. knowlesi to adapt and evolve within the human population.

\section{Adaptation of P. knowlesi to Human RBCs}

Consistent with $P$. knowlesi being a zoonosis of humans derived by transmission from macaque monkeys, in vitro culture of $P$. knowlesi has always been performed in macaque blood, because the low replication rate in human blood has impeded continuous propagation (Kocken et al. 2002). Interestingly, it was found that P. knowlesi parasites used in malaria therapy of neurosyphilis human patients resulted in high parasitemia infections and pathogenesis with increased passage through humans, suggesting an adaptation toward virulence (van Rooyen and Pile 1935; Ciuca et al. 1955). Recently, both our group and another group successfully obtained P. knowlesi lines adapted to grow efficiently in human RBCs (Lim et al. 2013; Moon et al. 2013). In both cases, the parental $P$. knowlesi $\mathrm{H}$ strain was in culture for an extended period of time in a mixture of human and macaque RBCs, until it was able to be maintained in purely human RBCs. The increased invasion efficiency observed in the humanadapted lines remains reliant on the $\operatorname{PkDBP} \alpha-$ DARC interaction (Moon et al. 2013). Interest- 
ingly, we found that although the parental strain showed a strong preference for the very young fraction of circulating human RBCs, the human-adapted line had circumvented this specific tropism, permitting invasion of an expanded pool of RBCs of varying age (Lim et al. 2013). Whether this mechanism mirrors the natural mode of adaptation in the field is yet to be determined. Increased numbers of human infections, particularly those of high density, may serve as a sentinel of increased adaptation of $P$. knowlesi to the human population.

\section{P. vivax: STRENGTH IN DIVERSITY}

\section{Diversity and Origin of $P$. vivax}

Despite being the most widely distributed of the human malaria parasites, $P$. vivax has long been considered benign and has not received as much attention as the demonstrably lethal $P$. falciparum. It is becoming apparent that $P$. vivax parasites are considerably more diverse than $P$. falciparum (Rosenberg et al. 1989; Qari et al. 1991, 1992; Cui et al. 2003; Neafsey et al. 2012; Carlton et al. 2013). In a recent study, next-generation sequencing of four geographically distinct P. vivax isolates (Neafsey et al. 2012) revealed a high rate of single-nucleotide polymorphisms (SNPs). P. vivax therefore has a larger effective population size compared with $P$. falciparum that has not gone through a recent bottleneck or drug-driven sweep in selection.

Analysis of a growing number of samples from different geographical locations has also led to the discovery of "P. vivax-like" parasites such as Plasmodium simium (Coatney et al. 1971; Costa et al. 2014). P. simium, found in New World monkeys, is considered to be morphologically and genetically indistinguishable from P. vivax (Collins et al. 1969; Coatney et al. 1971; Deane 1988). A recent study showed that wild monkeys infected with $P$. simium showed high levels of seropositivity against P. vivax antigens (Camargos Costa et al. 2015). Sequencing of the PsDBP gene revealed only four polymorphic sites compared with PvDBP, highlighting the remarkable similarity between $P$. vivax and $P$. simium and suggesting a poten- tially large sylvatic reservoir for $P$. vivax or $P$. vivax-like parasites.

Two other Plasmodium species closely related to $P$. vivax have also been identifiedPlasmodium cynomolgi and Plasmodium simiovale. Antibodies against the circumsporozoite protein of $P$. simiovale were detected in human population studies (Qari et al. 1993; Udhayakumar et al. 1994; Marrelli et al. 1998); however, an independent study could not confirm the presence of $P$. simiovale in the human population (Gopinath et al. 1994) and experimental infection of humans with $P$. simiovale in an early study was not successful (Dissanaike 1965). A recent analysis of the sequence of merozoite surface protein 9 (MSP-9) from diverse Plasmodium species suggests that $P$. simiovale and the macaque parasite, Plasmodium fieldi, form a clade, whereas $P$. vivax and $P$. cynomolgi form another (Chenet et al. 2013), arguing for a more in-depth phylogenetic analysis of this species. Interestingly, a case of $P$. cynomolgi human infection has been reported recently in Malaysia, showing the biological ability of this parasite to naturally infect humans ( $\mathrm{Ta}$ et al. 2014).

Where does $P$. vivax originally come from? The position of $P$. vivax within a clade of related parasites that includes $P$. cynomolgi, which infects Asian primates, led to the widely held view that $P$. vivax originated in Asia. This theory, however, was at odds with the near-fixation of the DARC-negative allele in sub-Saharan Africa, which largely confers protection against $P$. vivax (Young et al. 1955; Miller et al. 1975). Several recent studies have identified $P$. vivax-like parasites in African great apes (Kaiser et al. 2010; Krief et al. 2010; Prugnolle et al. 2010). A largescale study by Liu et al. (2014) found a much greater diversity of $P$. vivax in African great apes than found within the human population. The extant African ape reservoir of $P$. vivax likely descended from an ancient parasite pool, which served as a source for a single zoonotic transfer that has given rise to modern human $P$. vivax. Interestingly, the ape $P$. vivax-like parasites can infect both gorillas and chimpanzees alike, suggesting frequent transmission between these species. The reduced diversity of extant human $P$. vivax likely results from a bottlenecked line- 
C. Lim et al.

age that spread from Africa, where, thereafter, it became severely restricted within Africa as DARC negativity spread among the human population.

The PvDBP-DARC Interaction: Indispensable for $P$. vivax?

Three invasion ligands had been identified for P. vivax (PvDBP, PvRBP1, and PvRBP2) (Wertheimer and Barnwell 1989; Galinski et al. 1992) before the assembly of the full genome, which thereafter revealed the presence of several more members of the RBL family (Fig. 1) (Carlton et al. 2008). The interaction of PvDBP with the DARC receptor, however, had been shown to be essential for human infection (Miller et al. 1975; Wertheimer and Barnwell 1989).

De novo assembly of additional $P$. vivax isolates revealed that the SalI reference strain, which had been extensively passaged in vivo in monkey models, was missing several large genomic regions including loci for putative invasion ligands of both the RBL and DBL family (Hester et al. 2013). In addition, a duplication of PvDBP (Ménard et al. 2013) was observed in several field isolates, an apparently recent event, based on the similarity of the two DBP loci. In any case, $P$. vivax possesses a large set of invasion ligands that could be used to confer phenotypic diversity.

A number of reports have recently documented $P$. vivax infection in several DARC-negative individuals (Ménard et al. 2010a,b; Woldearegai et al. 2013). Additionally, cases of high parasitemia and severe disease caused by $P$. vivax have been increasing over the past decade (White et al. 2014). These discoveries suggest a diversity in the ability of $P$. vivax isolates to infect human RBCs.

\section{A Hidden Pool of $P$. vivax in Plain Sight?}

P. vivax can consistently be detected in the few DARC-positive individuals that are surveyed in largely DARC-negative populations (Culleton and Carter 2012). DARC-negative individuals also show significant exposure in populations of almost exclusive DARC negativity. Striking- ly, samples collected by passive case detection from $13 \%$ of individuals attending a clinic in the Republic of Congo had antibodies to the preerythrocytic stage of $P$. vivax (Culleton et al. 2009). These studies support the hypothesis that there is ongoing transmission of $P$. vivax in sub-Saharan Africa, although the extent of this "transmission" has not been fully assessed. It has been suggested that the small population of DARC-positive individuals $(<5 \%)$ may be sufficient to sustain this highly transmissible species. Further, it is possible that there exists a large reservoir of $P$. vivax in humans with a very low circulating parasitemia, which, nevertheless, can be transmitted to humans. The growing number of $P$. vivax cases in DARC-negative individuals adds yet another challenge. The discovery of $P$. vivax in gorillas and chimpanzees now provides the additional complexity of an animal reservoir. In fact, an expanded NHP reservoir could exist in many geographical areas as $P$. vivax and related species have also been found in various South American monkeys, including howler monkeys (Costa et al. 2014). A human traveler from the Central African Republic infected with ape $P$. vivax (Prugnolle et al. 2013), the lone case of a modern zoonotic transfer of this parasite species, suggests that if interaction between the human and NHP populations increases, risk of animal-borne $P$. vivax may increase in the human population.

\section{Challenges for Establishing a $P$. vivax Blood- Stage Vaccine}

Efforts to develop preventative measures against malaria have been heavily skewed toward $P$. falciparum (discussed later in this review) (Reyes-Sandoval 2013). It is becoming apparent that this lag in research in $P$. vivax control and prevention will be a major and persistent challenge in our goal toward malaria elimination (WHO 2015). The search for an ideal bloodstage vaccine target has centered on PvDBP because of its necessity in invading human RBCs. Antibodies raised against the binding region of PvDBP, called region II (RII), have been shown to be efficient at inhibiting the binding of PvDBP to DARC (Chitnis and Sharma 2008). 
PvRII has also shown promise in preclinical trials in animal models (Mueller et al. 2009). However, the high diversity among $P$. vivax strains and in the PvDBP alleles has led to conflicting reports on whether a PvRII-based vaccine would confer protection against all strains (de Sousa et al. 2014). Although there are a few more antigens under consideration as blood-stage vaccine targets (such as merozoite surface protein 1 [MSP-1] and apical membrane antigen 1 [AMA-1]), there is clearly a need to screen a larger set of antigens to find a more suitable one (Valencia et al. 2011). In addition, as the community decides how and where to concentrate vaccine development resources, several unique features of $P$. vivax should be considered, such as its higher transmissibility compared with P. falciparum (Brown et al. 2009) and its tendency to cause relapse in patients as a result of the elusive hypnozoite stage. Other life-cycle stages such as the preerythrocytic or transmission stages may thus be better to target in developing an efficient vaccine for $P$. vivax; indeed, efforts to interrupt these stages have been more successful (Reyes-Sandoval 2013).

\section{P. falciparum: THE MALIGNANT MALARIA}

\section{Origin of $P$. falciparum}

The origin of the deadly P. falciparum has been the subject of intense study. Until recently, the only identified parasite species closely related to P. falciparum in the Laverania sublineage was the chimpanzee parasite Plasmodium reichenowi. There were various hypotheses offered about the origin of $P$. falciparum with genetic evidence suggesting that it arose from $P$. reichenowi, likely by a single host transfer from chimpanzees to humans (Rich et al. 2009). Subsequent studies identified two other $P$. falciparum-related chimpanzee parasites Plasmodium gaboni (Ollomo et al. 2009) and Plasmodium billcollinsi (Krief et al. 2010). Nevertheless, seminal work by Liu et al. (2010), revealed that P. falciparum originated from a single host transfer from gorillas and not chimpanzees. $P$. falciparum was found to be most closely related to a
Plasmodium species isolated from Western gorillas, later termed Plasmodium praefalciparum (Rayner et al. 2011). This study, which relied on amplification of mitochondrial sequences from single copies of Plasmodium genomes from ape fecal samples, also revealed a diversity of closely related Laverania species displaying specificity for either gorilla or chimpanzee hosts (Fig. 2).

The potential for closely related great ape parasites such as $P$. praefalciparum to infect humans does not presently appear to be significant (Sundararaman et al. 2013; Délicat-Loembet et al. 2015), with $P$. falciparum clearly emerging from a single ancient transmission event. Conversely, $P$. falciparum has been found to infect bonobos and gorillas as an anthroponosis, which raises concerns about potential animal reservoirs of $P$. falciparum. However, most of the $P$. falciparum-infected great apes were captive and living in close proximity to humans (Krief et al. 2010; Prugnolle et al. 2010), suggesting that such a threat is low and will not undermine elimination efforts, as long as humans continue to live apart from great apes or treat captive apes with antimalarials.

\section{Diversity in Invasion Ligands}

A comparison of the $P$. reichenowi and $P$. falciparum genome sequences implicates RBL and DBL invasion ligands as factors associated with adaptation to a host species. Although the two genomes are highly similar, the loci for several orthologous invasion ligands in the two species are extensively differentiated between species, as evidenced by pseudogenization, disruptions in gene synteny, and sequence divergence (Otto et al. 2014). Variant expression of invasion ligands in laboratory-adapted and field strains has shown the differential usage of ligand-receptor interactions between $P$. falciparum isolates for the invasion of RBCs (Reed et al. 2000; Duraisingh et al. 2003a,b; Nery et al. 2006; Bei et al. 2007; Jennings et al. 2007; Gomez-Escobar et al. 2010). The use of diverse ligand-receptor pairs is thought to be both a mechanism of immune evasion and a means to invade diverse RBC subtypes within an individ- 
C. Lim et al.

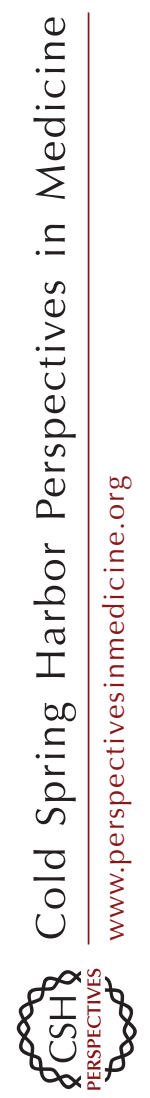

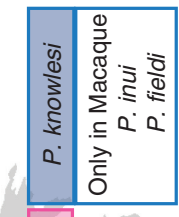
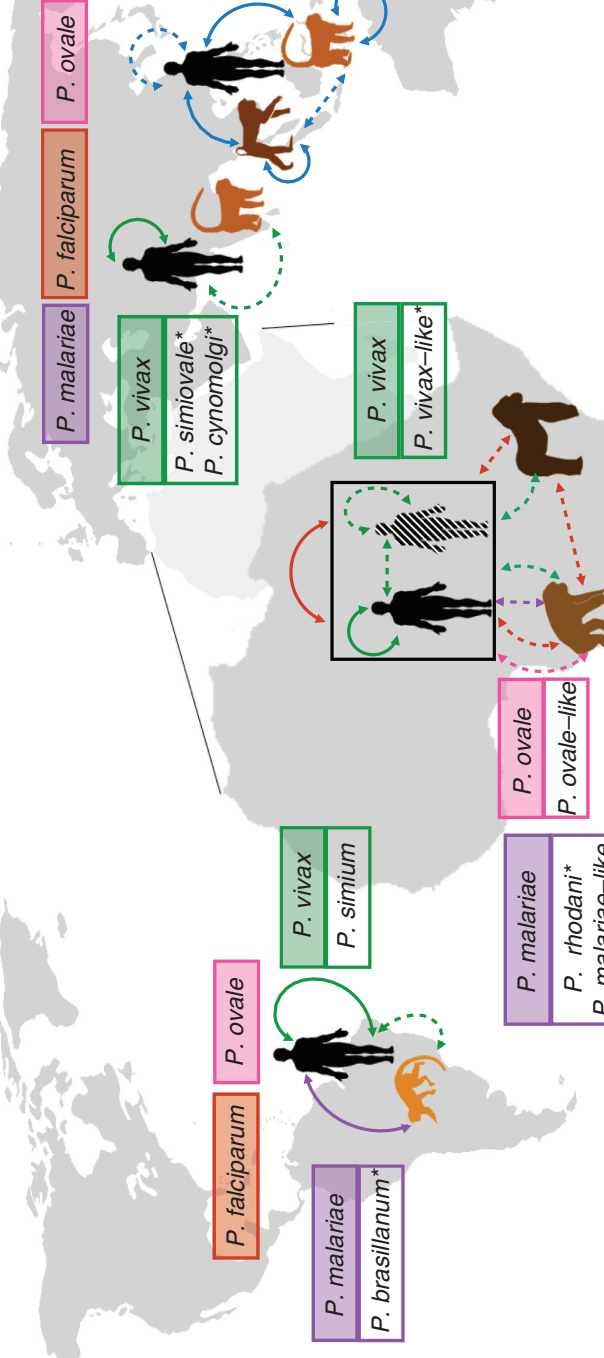

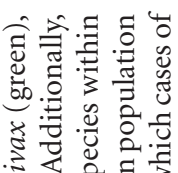

इस क्ष $\approx$ है

홀

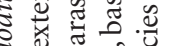

of

Q

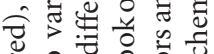

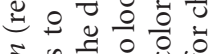

₹

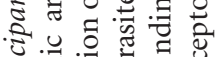

उ.

ई च्जे

홍

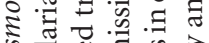

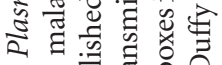

เ

..$\Xi$ 造..

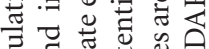

응 5 :

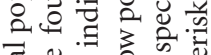

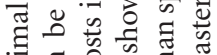

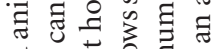

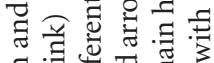

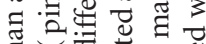

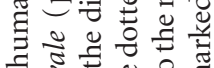

둘

₹

.

के एव

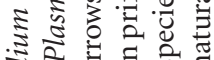

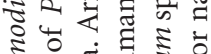

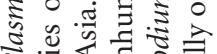

2.

पे के चै है

o

. 3 过

छี

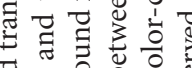

च 己0

जै

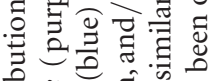

ㄴ.

कू

च

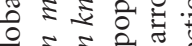

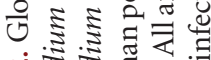

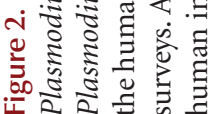


ual, between individuals, and even potentially between host species.

\section{Sialic Acid and Host Specificity}

The sialic acid on RBCs appears to be key to the binding of many invasion ligands of $P$. falciparum, including the DBL invasion ligands, PfEBA-175, PfEBL-1, PfEBA-140, and PfEBA181 , and the RBL invasion ligand Rh1 (Orlandi et al. 1992; Gilberger 2003; Lobo 2003; Maier et al. 2003; Triglia et al. 2005; Mayer et al. 2009). Some strains are highly dependent on the presence of sialic acid for successful invasion, whereas other strains can invade in a sialic acid-independent fashion (Stubbs et al. 2005; Gaur et al. 2006). Humans express only the $N$ acetylneuraminic acid (Neu5Ac) form of sialic acid, because of an inactivating mutation in the enzyme cytidine monophosphate $N$-acetylneuraminic acid hydroxylase (CMAH), which otherwise converts Neu5Ac to $\mathrm{N}$-glycolylneuraminic acid (Neu5Gc) (Chou et al. 1998; Irie et al. 1998; Hayakawa et al. 2001). In contrast to humans, all great apes have an intact $C M A H$ gene and express a high degree of Neu5Gc on their RBC surface (Muchmore et al. 1998).

It has been postulated that this chemical difference in sialic acid between humans and other great apes might influence the specificity of Laverania parasites for their hosts. Chimpanzees can be experimentally infected with P. falciparum (Blacklock and Adler 1922; Daubersies et al. 2000); however, natural infections of wild-living chimpanzees have not been observed (Liu et al. 2010). Evidence to date suggests that $P$. reichenowi does not infect humans (Blacklock and Adler 1922; Bruce-Chwatt et al. 1970). One study showed that PfEBA-175 and $P$. reichenowi EBA-175 preferentially bind to RBCs of their own host species and erythroidlike cells expressing the host-specific sialic acid (Martin et al. 2005). The investigators further showed that Aotus monkeys, which serve as model organisms for $P$. falciparum (Herrera et al. 2002) express Neu5Ac, potentially explaining their susceptibility to $P$. falciparum infection. However, it was subsequently observed that PfEBA-175 binds to both Neu5Ac and
Neu5Gc (Wanaguru et al. 2013), contradicting previous findings (Martin et al. 2005), but potentially providing an explanation for the ability of Neu5Gc to potently inhibit binding of PfEBA-175 to human RBCs (Orlandi et al. 1992). Indeed, homologs of EBA-175 from $P$. reichenowi and $P$. billcollinsi, another chimpanzee parasite, bind human RBCs as well as human glycophorin A with similar affinities, suggesting that perhaps EBA-175 is not a major tropism determinant for these species (Wanaguru et al. 2013).

\section{PfRh5 as a Host Restriction Factor}

Of the RBL and DBL invasion ligands, PfRh5 is the only established invasion ligand that has been found to be essential for RBC invasion by all $P$. falciparum strains tested to date (Crosnier et al. 2011). Interestingly, polymorphisms in this molecule are associated with invasion into Aotus RBCs, through mapping using the progeny of a genetic cross (Hayton et al. 2008, 2013). Subsequently, it was found that PfRh5 binds chimpanzee and gorilla basigin (BSG) at much reduced levels compared with human BSG, suggesting that the molecule might be critical in defining the specificity of $P$. falciparum for human RBCs. Specific amino acid residues in BSG were identified that contribute to recognition of human BSG by PfRh5. Notably, two of these residues, F27 and K191, were identified as targets of positive selection in a study using population genetics and phylogenetics (Forni et al. 2015), providing further evidence that this key receptor is under selection pressure both within the human lineage and during NHP evolution.

Targeting the Tropism Ligands of $P$. falciparum for Vaccine Development

Sterile immunity to $P$. falciparum infectionthe ultimate goal of a malaria vaccine-does not occur in naturally exposed human populations. Instead, individuals acquire partial immunity with age (Persson et al. 2008; Badiane et al. 2013), likely a result of continual exposure to Plasmodium infections and gradual acquisi- 
C. Lim et al.

tion of antibodies against parasite antigens, including many invasion ligands. The merozoite invasion ligands have been proposed as vaccine candidates. However, inclusion of multiple antigens in an invasion-blocking vaccine would be necessary to effectively counter the ability of P. falciparum to use different invasion pathways and overcome sequence polymorphism of invasion ligands (Nery et al. 2006; Bowyer et al. 2015; Mensah-Brown et al. 2015). Many studies have reported the presence of invasion-inhibitory antibodies acquired toward $P$. falciparum DBL ligands, (PfEBA-175, PfEBA-140, PfEBA181 ) and RBL ligands (PfRh2 and PfRh4) (Ford et al. 2007; Persson et al. 2008; Reiling et al. 2010; Reiling et al. 2012; Badiane et al. 2013). Recent studies have shown that simultaneous blockade of multiple invasion ligand-receptor interactions can synergistically inhibit invasion (Lopaticki et al. 2011; Williams et al. 2012; Pandey et al. 2013), showing the potential of such a vaccine strategy. Recently, several in vitro-based culture studies have shown the strong potential of the essential invasion ligand PfRh5 as an antigenic target for inhibition (Douglas et al. 2011, 2014; Patel et al. 2013; Reddy et al. 2014). Additionally, administration of a PfRh5-based experimental vaccine blocks $P$. falciparum infection in Aotus monkeys following parasite inoculation (Douglas et al. 2015). It is possible that a major challenge to elimination of $P$. falciparum by vaccine strategies targeting invasion ligands is the polymorphism and redundancy that might allow the parasites to persist in reservoirs such as young RBCs that can be invaded using hitherto unidentified ligand-receptor interactions.

\section{THE OTHER PLASMODIA: AN UNEXPECTED DIVERSITY}

Although $P$. ovale and $P$. malariae are understudied relative to other human malaria parasites, they contribute significantly to the global malaria burden. The distribution of $P$. ovale is thought to be limited to some tropical areas in Africa, New Guinea, and parts of the Philippines and Indonesia (Mueller et al. 2007). Its global burden may, however, be an underesti- mation, as $P$. ovale presents with low parasitemia and is easy to miss or misdiagnose as the morphologically similar and more prevalent $P$. vivax. Diagnosis became more sensitive and accurate with the development of a species-specific polymerase chain reaction (PCR) method (Snounou et al. 1993). However, some cases identified as $P$. ovale by light microscopy could not be detected by this method because of strong genetic variation (Tachibana et al. 2002; Win et al. 2004; Calderaro et al. 2007) among analyzed samples. It took several years after these observations for Sutherland et al. (2010) to show that the "classic" and "variant" types of $P$. ovale are in fact two distinct subspecies that are nonrecombining but sympatric in endemic regions.

Similarly, variant forms of P. malariae, not detectable through the standard species-specific PCR, have been observed in distinct endemic regions, such as China and Southeast Asia (Kawamoto et al. 1999). The same variant sequence was found in distinct geographical regions, indicating the presence of a stable and common form of $P$. malariae. Further investigation will determine whether this is another existing or ongoing speciation event.

Both $P$. ovale-like and P. malariae-like species have been detected in African great apes, albeit at a much lower frequency than the Laverania clade, in the study conducted by Liu and colleagues (2010). This discovery warrants further investigation to determine whether these neglected species are also more widely prevalent than assumed. In addition, historical observations suggest that $P$. malariae may be able to infect a larger range of host species; P. brasilianum, a parasite in South American monkeys and $P$. rhodaini, found in African chimpanzees are morphologically similar to $P$. malariae and show similar disease progression. They can both be transmitted to humans experimentally, and it has been suggested that this species might indeed be P. malariae (Coatney 1968; Rayner 2015). Genetic analysis now suggests that P. malariae can infect Old and New World monkeys as well as humans, presenting a formidable zoonotic reservoir for $P$. malariae (Lalremruata et al. 2015). 


\section{PERSPECTIVES: WHAT WILL WE NEED TO REACH ELIMINATION?}

\section{Defining the Extent of Zoonotic Reservoirs: Continuous Surveying and Sampling}

Emergence of new zoonoses would rely on a number of criteria being favorable, including the probability of contact between human and animal host, shared mosquito vectors, and RBC-stage infectivity. This is well-discussed in a review, in which J.K. Baird, writing before the discovery of multiple Laverania species, assesses the risk of 18 non-Laverania NHP species and one Laverania species found in different geographic regions to cause human infection (Baird 2009). He concludes that only three species have great potential to be zoonoticP. knowlesi, which is already well established as a human parasite, $P$. cynomolgi, for which there has been one report of a natural human infection ( $\mathrm{Ta}$ et al. 2014), and Plasmodium inui, which is often found in the same natural hosts and vectors as $P$. knowlesi.

Today, our knowledge of the extent to which we are exposed to Plasmodium species has come primarily from direct surveys of individuals, animal hosts, and mosquito vectors in malariaendemic regions. Modern-day efforts to determine the bounds of the P. knowlesi zoonotic reservoir have relied on sampling of wild macaques (Lee et al. 2011; Moyes et al. 2014), which helps prioritize areas of high-transmission risk, but as the investigators note, the animal reservoir may extend beyond the known natural hosts. It is also important to obtain whole-genome sequences of $P$. knowlesi from macaque reservoirs to fully detect evidence of selection and potential host switching. Although Laverania parasites, appear to have limited potential to cause zoonotic infections in the populations studied (Sundararaman et al. 2013; Délicat-Loembet et al. 2015), longitudinal surveys covering wider regions may provide more definitive evidence. Further sensitive and specific detection methods will be crucial in defining the extent of the reservoir.

Although not discussed in this review, vector surveys and studies will also be required to provide evidence for transmission to hu- mans under favorable conditions (Vythilingam 2010; Paupy et al. 2013; Maeno et al. 2015).

Critical Review of Hospital Records and Case Studies for Early Detection of Unusual Cases

Although host and vector sampling are very useful in assessing the risk of zoonotic infections, they require extensive resources and can be impractical. Hospital records have proven invaluable in documenting cases of interest. Indeed, case reports and hospital records have led to many of the important reevaluations of dogma discussed in this review, including cases of $P$. vivax in DARC-negative individuals (Rubio et al. 1999), possible zoonotic $P$. vivax (Prugnolle et al. 2013), and the first case of P. cynomolgi human infection ( Ta et al. 2014). Many of these findings, however, rely on correct diagnosis on site. Diagnosis based on morphology is prone to mistakes ( $P$. knowlesi misdiagnosed as P. malariae, or $P$. ovale and possibly $P$. cynomolgi as $P$. vivax) and it is critical that molecular tools be used to definitively identify Plasmodium species. Increased awareness of the presence of these parasites in endemic regions will be important in early detection of unusual cases. This should also be accompanied with development of new rapid diagnostic tests that can detect and discriminate a larger range of species, as well as training of local public health staff.

\section{The Promise of In Vitro Experimental Advances}

The robust in vitro culture system accounts for our disproportionately greater knowledge of P. falciparum above other human Plasmodium species. Although advances in genomic tools are lending greater insight into the more neglected species, in vitro experiments will remain the gold standard to understand the mechanisms of invasion and host tropism. There have been substantial advances in studying $P$. vivax ex vivo (Russell et al. 2012) and even potential for genetic manipulation in vivo (Moraes Barros et al. 2014). There are reports of short-term culture of $P$. vivax in vitro (Golenda et al. 1997) and of P. malariae (Lingnau et al. 1994), but efforts to 
C. Lim et al.
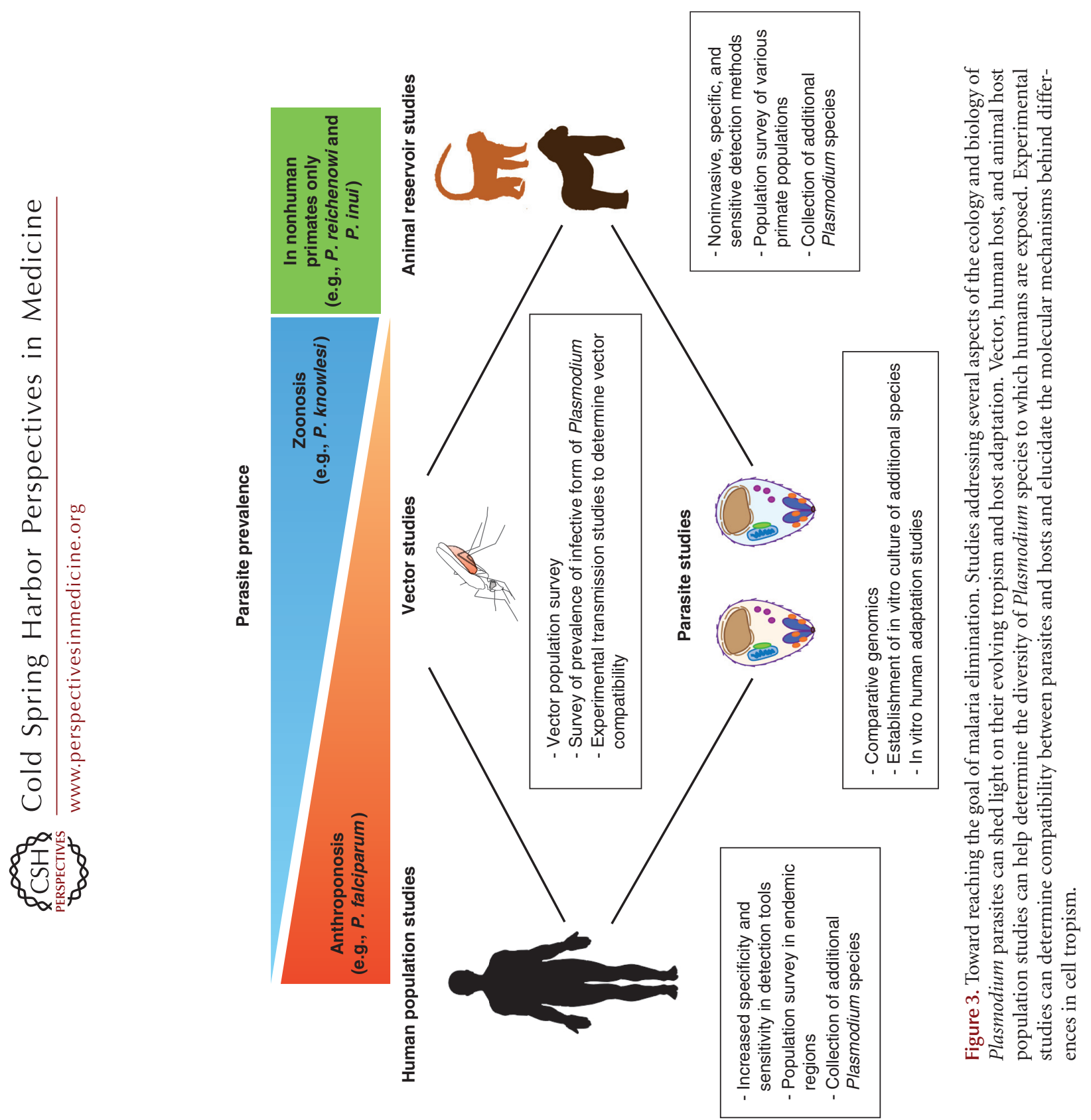
establish a reliable in vitro culture system should be renewed for these species, as well as P. ovale. In vitro culture will also facilitate initial screening of blood-stage vaccine targets for $P$. vivax and help identify promising candidates to pursue further. The success of adapting $P$. knowlesi to human blood has opened new doors in investigating mechanisms of host switch and adaptation relevant in the field, and has also provided the community with a more accessible tool for genetic manipulation because it obviates the need for macaque blood (Lim et al. 2013; Moon et al. 2013). Isolation of the newly identified parasites will be a daunting task but will provide a much-needed resource as we hopefully approach control if not eradication of the human Plasmodium species. Figure 3 summarizes studies that in conjunction will provide the necessary information for more efficient and relevant eradication strategies.

\section{CONCLUDING REMARKS}

Control of malaria has been a goal for the scientific community for several decades, while there is now a renewed emphasis on elimination. Most effort to date has focused mainly on $P$. falciparum and P. vivax, leaving the burden and prevalence of the lesser-studied species unclear. Having been comparatively understudied, the true extent of these parasites in humans and potential zoonotic reservoirs is not known. Expansion of current surveillance efforts to include all potential reservoirs might be needed. Methodologies with increased sensitivity will be essential for the detection of low parasitemia infections that are associated with the less-studied Plasmodium species. Continuous and more sensitive sampling and sequencing of human and animal Plasmodium species will keep us informed on the existing diversity and influence the elimination strategies to implement. Plasmodium parasites are continuously evolving, and molecular determinants leading to changes and expansion in host tropism will be key factors to investigate, which in some cases might identify critical molecules for development as vaccine candidates. Finally, it is also important to consider that human development is dramat- ically changing the ecology of infection, as human encroachment may create new and greater opportunities for potential animal reservoirs to transmit Plasmodium parasites.

\section{ACKNOWLEDGMENTS}

We thank James H. Mullen for his assistance with the figures.

\section{REFERENCES}

${ }^{*}$ Reference is also in this collection.

Ahmed AM, Pinheiro MM, Divis PC, Siner A, Zainudin R, Wong IT, Lu CW, Singh-Khaira SK, Millar SB, Lynch S, et al. 2014. Disease progression in Plasmodium knowlesi malaria is linked to variation in invasion gene family members. PLoS Negl Trop Dis 8: e3086.

Assefa S, Lim C, Preston MD, Duffy CW, Nair MB, Adroub SA, Kadir KA, Goldberg JM, Neafsey DE, Divis P, et al. 2015. Population genomic structure and adaptation in the zoonotic malaria parasite Plasmodium knowlesi. Proc Natl Acad Sci 112: 13027-13032.

Badiane AS, Bei AK, Ahouidi AD, Patel SD, Salinas N, Ndiaye D, Sarr O, Ndir O, Tolia NH, Mboup S, et al. 2013. Inhibitory humoral responses to the Plasmodium falciparum vaccine candidate EBA-175 are independent of the erythrocyte invasion pathway. Clin Vaccine Immunol 20: $1238-1245$.

Baird JK. 2009. Malaria zoonoses. Travel Med Infect Dis 7: $269-277$.

Barber BE, William T, Dhararaj P, Anderios F, Griff MJ, Yeo TW, Anstey NM. 2012. Epidemiology of Plasmodium knowlesi malaria in north-east Sabah, Malaysia: Family clusters and wide age distribution. Malaria J 11: 401.

Bei AK, Membi CD, Rayner JC, Mubi M, Ngasala B, Sultan AA, Premji Z, Duraisingh MT. 2007. Variant merozoite protein expression is associated with erythrocyte invasion phenotypes in Plasmodium falciparum isolates from Tanzania. Mol Biochem Parasitol 153: 66-71.

Blacklock B, Adler S. 1922. A parasite resembling Plasmodium falciparum in a chimpanzee. Ann Trop Med Parasitol 16: $99-106$.

Bowyer PW, Stewart LB, Aspeling-Jones H, Mensah-Brown HE, Ahouidi AD, Amambua-Ngwa A, Awandare GA, Conway DJ. 2015. Variation in Plasmodium falciparum erythrocyte invasion phenotypes and merozoite ligand gene expression across different populations in areas of malaria endemicity. Infect Immun 83: 2575-2582.

Brown GV, Moorthy VS, Reed Z, Mendis K, Arévalo-Herrera M, Alonso P; WHO MALVAC Committee. 2009. Priorities in research and development of vaccines against Plasmodium vivax malaria. Vaccine 27: 7228-7235.

Bruce-Chwatt LJ, Garnham PC, Shute PG, Draper CC. 1970. Induced double infection with Plasmodium vivax and $P$. falciparum in a splenectomized chimpanzee. Trans $R$ Soc Trop Med Hyg 64: 2. 
C. Lim et al.

Calderaro A, Piccolo G, Perandin F, Gorrini C, Peruzzi S, Zuelli C, Ricci L, Manca N, Dettori G, Chezzi C, et al. 2007. Genetic polymorphisms influence Plasmodium ovale PCR detection accuracy. J Clin Microbiol 45: 1624-1627.

Camargos Costa D, Pereira de Assis GM, de Souza Silva FA, Araújo FC, de Souza Junior JC, Braga Hirano ZM, Satiko Kano F, Nóbrega de Sousa T, Carvalho LH, Ferreira Alves de Brito C. 2015. Plasmodium simium, a Plasmodium vivax-related malaria parasite: Genetic variability of Duffy binding protein II and the Duffy antigen/receptor for chemokines. PLoS ONE 10: e0131339.

Carlton JM, Silva JC, Bidwell SL, Adams JH, Silva JC, Bidwell SL, Lorenzi H, Caler E, Crabtree J, Angiuoli SV, Merino EF, Amedeo P, et al. 2008. Comparative genomics of the neglected human malaria parasite Plasmodium vivax. Nature 455: 757-763.

Carlton JM, Das A, Escalante AA. 2013. Genomics, population genetics and evolutionary history of Plasmodium vivax. Adv Parasitol 81: 203-222.

Chenet SM, Pacheco MA, Bacon DJ, Collins WE, Barnwell JW, Escalante AA. 2013. The evolution and diversity of a low complexity vaccine candidate, merozoite surface protein 9 (MSP-9), in Plasmodium vivax and closely related species. Infect Genet Evol 20: 239-248.

Chin W, Contacos PG, Coatney GR, Kimball HR. 1965. A naturally acquired quotidian-type malaria in man transferable to monkeys. Science 149: 865-865.

Chitnis CE, Sharma A. 2008. Targeting the Plasmodium vivax Duffy-binding protein. Trends Parasitol 24: 29-34.

Chou HH, Takematsu H, Diaz S, Iber J, Nickerson E, Wright KL, Muchmore EA, Nelson DL, Warren ST, Varki A. 1998. A mutation in human CMP-sialic acid hydroxylase occurred after the Homo-Pan divergence. Proc Natl Acad Sci 95: $11751-11756$.

Ciuca M, Chelarescu M, Sofletea A, Constantenescu P, Teriteanu E, Cortez P, et al. 1955. Contribution expérimentale a l'étude de l'immunité dans le paludisme. L'Academia, Bucharest, Romania.

Coatney GR. 1968. Simian malarias in man: Facts, implications, and predictions. Am J Trop Med Hyg 17: 147-155.

Coatney GR, Collins WE, Contacos PG. 1971. The primate malarias. U.S. National Institute of Allergy and Infectious Diseases, Washington, DC

Collins WE, Contacos PG, Guinn EG. 1969. Observations on the sporogonic cycle and transmission of Plasmodium simium Da Fonseca. J Parasitol 55: 814-816.

Costa DC, da Cunha VP, de Assis GM, de Souza Junior JC, Hirano ZM, de Arruda ME, Kano FS, Carvalho LH, de Brito CF. 2014. Plasmodium simium/Plasmodium vivax infections in southern brown howler monkeys from the Atlantic Forest. Mem Inst Oswaldo Cruz 109: 641-653.

Cowman AF, Crabb BS. 2006. Invasion of red blood cells by malaria parasites. Cell 124: 755-766.

Cowman AF, Berry D, Baum J. 2012. The cell biology of disease: The cellular and molecular basis for malaria parasite invasion of the human red blood cell. J Cell Biol 198: 961-971.

Cox Singh J, Culleton R. 2015. Plasmodium knowlesi: From severe zoonosis to animal model. Trends Parasitol 31: $232-238$.
Crosnier C, Bustamante LY, Bartholdson SJ, Bei AK, Theron M, Uchikawa M, Mboup S, Ndir O, Kwiatkowski DP, Duraisingh MT, et al. 2011. Basigin is a receptor essential for erythrocyte invasion by Plasmodium falciparum. $\mathrm{Na}$ ture 480: 534-537.

Cui L, Escalante AA, Imwong M, Snounou G. 2003. The genetic diversity of Plasmodium vivax populations. Trends Parasitol 19: 220-226.

Culleton R, Carter R. 2012. African Plasmodium vivax: Distribution and origins. Int J Parasitol 42: 1091-1097.

Culleton R, Ndounga M, Zeyrek FY, Coban C, Casimiro PN, Takeo S, Tsuboi T, Yadava A, Carter R, Tanabe K. 2009. Evidence for the transmission of Plasmodium vivaxin the Republic of the Congo, West Central Africa. J Infect Dis 200: $1465-1469$.

Daneshvar C, Davis TM, Cox-Singh J, Rafa'ee MZ, Zakaria SK, Divis PC, Singh B. 2009. Clinical and laboratory features of human Plasmodium knowlesi infection. Clin Infect Dis 49: 852-860.

Daubersies P, Thomas AW, Millet P, Brahimi K, Langermans JA, Ollomo B, BenMohamed L, Slierendregt B, Eling W, Van Belkum A, et al. 2000. Protection against Plasmodium falciparum malaria in chimpanzees by immunization with the conserved pre-erythrocytic liver-stage antigen 3. Nat Med 6: 1258-1263.

Deane LM. 1988. Malaria studies and control in Brazil. Am J Trop Med Hyg 38: 223-230.

Délicat-Loembet L, Rougeron V, Ollomo B, Arnathau C, Roche B, Elguero E, Moukodoum ND, Okougha AP, Mve Ondo B, Boundenga L, et al. 2015. No evidence for ape Plasmodium infections in humans in Gabon. PLoS ONE 10: e0126933.

de Sousa TN, Kano FS, de Brito CFA, Carvalho LH. 2014. The Duffy binding protein as a key target for a Plasmodium vivax vaccine: Lessons from the Brazilian Amazon. Mem Inst Oswaldo Cruz 109: 608-617.

Dissanaike AS. 1965. Simian malaria parasites of Ceylon. Bull World Health Organ 32: 593-597.

Divis PCS, Singh B, Anderios F, Hisam S, Matusop A, Kocken CH, Assefa SA, Duffy CW, Conway DJ. 2015. Admixture in humans of two divergent Plasmodium knowlesi populations associated with different macaque host species. PLoS Pathog 11: e1004888-17.

Douglas AD, Williams AR, Illingworth JJ, Kamuyu G, Biswas S, Goodman AL, Wyllie DH, Crosnier C, Miura K, Wright GJ, et al. 2011. The blood-stage malaria antigen PfRH5 is susceptible to vaccine-inducible cross-strain neutralizing antibody. Nat Commun 2: 601-619.

Douglas AD, Williams AR, Knuepfer E, Illingworth JJ, Furze JM, Crosnier C, Choudhary P, Bustamante LY, Zakutansky SE, Awuah DK, et al. 2014. Neutralization of Plasmodium falciparum merozoites by antibodies against PfRH5. J Immunol 192: 245-258.

Douglas AD, Baldeviano GC, Lucas CM, Lugo-Roman LA, Crosnier C, Bartholdson SJ, Diouf A, Miura K, Lambert LE, Ventocilla JA, et al. 2015. A PfRH5-based vaccine is efficacious against heterologous strain blood-stage Plasmodium falciparum infection in Aotus monkeys. Cell Host Microbe 17: 130-139.

Duraisingh MT, Triglia T, Ralph SA, Rayner JC, Barnwell JW, McFadden GI, Cowman AF. 2003a. Phenotypic variation of Plasmodium falciparum merozoite proteins directs re- 
ceptor targeting for invasion of human erythrocytes. EMBO J 22: 1047-1057.

Duraisingh MT, Maier AG, Triglia T, Cowman AF. 2003b. Erythrocyte-binding antigen 175 mediates invasion in Plasmodium falciparum utilizing sialic acid-dependent and -independent pathways. Proc Natl Acad Sci 100: 4796-4801.

Ford L, Lobo CA, Rodriguez M, Zalis MG, Machado RL, Rossit AR, Cavasini CE, Couto AA, Enyong PA, Lustigman S. 2007. Differential antibody responses to Plasmodium falciparum invasion ligand proteins in individuals living in malaria-endemic areas in Brazil and Cameroon. Am J Trop Med Hyg 77: 977-983.

Fornace KM, Nuin NA, Betson M, Grigg MJ, William T, Anstey NM, Yeo TW, Cox J, Ying LT, Drakeley CJ. 2015. Asymptomatic and submicroscopic carriage of Plasmodium knowlesi malaria in household and community members of clinical cases in Sabah, Malaysia. J Infect Dis 213: 784-787.

Forni D, Pontremoli C, Cagliani R, Pozzoli U, Clerici M, Sironi M. 2015. Positive selection underlies the speciesspecific binding of Plasmodium falciparum RH5 to human basigin. Mol Ecol 24: 4711-4722.

Galinski MRM, Medina CCC, Ingravallo PP, Barnwell JWJ. 1992. A reticulocyte-binding protein complex of Plasmodium vivax merozoites. Cell 69: 1213-1226.

Gaur D, Furuya T, Mu J, Jiang LB, Su XZ, Miller LH. 2006. Upregulation of expression of the reticulocyte homology gene 4 in the Plasmodium falciparum clone Dd2 is associated with a switch in the erythrocyte invasion pathway. Mol Biochem Parasitol 145: 205-215.

Gilberger TW, Thompson JK, Triglia T, Good RT, Duraisingh MT, Cowman AF. 2003. A novel erythrocyte binding antigen-175 paralogue from Plasmodium falciparum defines a new trypsin-resistant receptor on human erythrocytes. J Biol Chem 278: 14480-14486.

Golenda CF, Li J, Rosenberg R. 1997. Continuous in vitro propagation of the malaria parasite Plasmodium vivax. Proc Natl Acad Sci 94: 6786-6791.

Gomez-Escobar N, Amambua Ngwa A, Walther M, Okebe J Ebonyi A, Conway DJ. 2010. Erythrocyte invasion and merozoite ligand gene expression in severe and mild Plasmodium falciparum malaria. J Infect Dis 201: 444-452.

Gopinath R, Wongsrichanalai C, Cordón-Rosales C, Mirabelli L, Kyle D, Kain KC. 1994. Failure to detect a Plasmodium vivax-like malaria parasite in globally collected blood samples. J Infect Dis 170:1630-1633.

Hayakawa T, Satta Y, Gagneux P, Varki A, Takahata N. 2001. Alu-mediated inactivation of the human CMP- $N$-acetylneuraminic acid hydroxylase gene. Proc Natl Acad Sci 98: 11399-11404.

Haynes JD, Dalton JP, Klotz FW, McGinniss MH, Hadley TJ, Hudson DE, Miller LH. 1988. Receptor-like specificity of a Plasmodium knowlesi malarial protein that binds to Duffy antigen ligands on erythrocytes. J Exp Med 167: 1873-1881.

Hayton K, Gaur D, Liu A, Takahashi J, Henschen B, Singh S, Lambert L, Furuya T, Bouttenot R, Doll M, et al. 2008 Erythrocyte binding protein PfRH5 polymorphisms determine species-specific pathways of Plasmodium falciparum invasion. Cell Host Microbe 4: 40-51.
Hayton K, Dumoulin P, Henschen B, Liu A, Papakrivos J, Wellems TE. 2013. Various PfRH5 polymorphisms can support Plasmodium falciparum invasion into the erythrocytes of owl monkeys and rats. Mol Biochem Parasitol 187: $103-110$.

Herrera S, Perlaza BL, Bonelo A, Arévalo-Herrera M. 2002. Aotus monkeys: Their great value for anti-malaria vaccines and drug testing. Int J Parasitol 32: 1625-1635.

Hester J, Chan ER, Menard D, Mercereau-Puijalon O, Barnwell J, Zimmerman PA, Serre D. 2013. De novo assembly of a field isolate genome reveals novel Plasmodium vivax erythrocyte invasion genes. PLoS Negl Trop Dis 7: e2569.

Irie A, Koyama S, Kozutsumi Y, Kawasaki T, Suzuki A. 1998. The molecular basis for the absence of $N$-glycolylneuraminic acid in humans. J Biol Chem 273: 15866-15871.

Jennings CV, Ahouidi AD, Zilversmit M, Bei AK, Rayner J, Sarr O, Ndir O, Wirth DF, Mboup S, Duraisingh MT. 2007. Molecular analysis of erythrocyte invasion in Plasmodium falciparum isolates from Senegal. Infect Immun 75: 3531-3538.

Jones KE, Patel NG, Levy MA, Storeygard A, Balk D, Gittleman JL, Daszak P. 2008. Global trends in emerging infectious diseases. Nature 451: 990-993.

Kaiser M, Löwa A, Ulrich M, Ellerbrok H, Goffe AS, Blasse A, Zommers Z, Couacy-Hymann E, Babweteera F, Zuberbühler K, et al. 2010. Wild chimpanzees infected with 5 Plasmodium species. Emerg Infect Dis 16: 1956-1959.

Kawamoto F, Liu Q, Ferreira MU, Tantular IS. 1999. How prevalent are Plasmodium ovale and P. malariae in East Asia? Parasitol Today 15: 422-426.

Kocken $\mathrm{CH}$, Ozwara $\mathrm{H}$, van der Wel A, Beetsma $\mathrm{AL}$, Mwenda JM, Thomas AW. 2002. Plasmodium knowlesi provides a rapid in vitro and in vivo transfection system that enables double-crossover gene knockout studies. Infect Immun 70: 655-660.

Krief S, Escalante AA, Pacheco MA, Mugisha L, André C, Halbwax M, Fischer A, Krief JM, Kasenene JM, Crandfield M, et al. 2010. On the diversity of malaria parasites in African apes and the origin of Plasmodium falciparum from Bonobos. PLoS Pathog 6: e1000765.

Lalremruata A, Magris M, Vivas-Martínez S, Koehler M, Esen M, Kempaiah P, Jeyaraj S, Perkins DJ, Mordmüller B, Metzger WG. 2015. Natural infection of Plasmodium brasilianum in humans: Man and monkey share quartan malaria parasites in the Venezuelan Amazon. EBioMedicine 2: 1186-1192.

Lee KS, Cox-Singh J, Brooke G, Matusop A, Singh B. 2009. Plasmodium knowlesi from archival blood films: Further evidence that human infections are widely distributed and not newly emergent in Malaysian Borneo. Int J Parasitol 39: 1125-1128.

Lee KS, Divis PCS, Zakaria SK, Matusop A, Julin RA, Conway DJ, Cox-Singh J, Singh B. 2011. Plasmodium knowlesi: Reservoir hosts and tracking the emergence in humans and macaques. PLoS Pathog 7: e1002015.

Lim C, Hansen E, DeSimone TM, Moreno Y, Junker K, Bei A, Brugnara C, Buckee CO, Duraisingh MT. 2013. Expansion of host cellular niche can drive adaptation of a zoonotic malaria parasite to humans. Nat Commun 4: 1638 1639. 
C. Lim et al.

Lingnau A, Doehring-Schwerdtfeger E, Maier WA. 1994 Evidence for 6-day cultivation of human Plasmodium malariae. Parasitol Res 80: 265-266.

Liu W, Li Y, Learn GH, Rudicell RS, Robertson JD, Keele BF, Ndjango JB, Sanz CM, Morgan DB, et al. 2010. Proc Natl Acad Sci 102: 12819-12824.

Liu W, Li Y, Shaw KS, Learn GH, Plenderleith LJ, Malenke JA, Sundararaman SA, Ramirez MA, Crystal PA, Smith AG, et al. 2014. African origin of the malaria parasite Plasmodium vivax. Nat Commun 5: 1-10.

Lobo CA, Rodriguez M, Reid M, Lustigman S. 2003. Glycophorin $\mathrm{C}$ is the receptor for the Plasmodium falciparum erythrocyte binding ligand PfEBP-2(baebl). Blood 101: 4628-4631.

Lopaticki S, Maier AG, Thompson J, Wilson DW, Tham WH, Triglia T, Gout A, Speed TP, Beeson JG, Healer J, et al. 2011. Reticulocyte and erythrocyte binding-like proteins function cooperatively in invasion of human erythrocytes by malaria parasites. Infect Immun 79: 1107-1117.

Maeno Y, Quang NT, Culleton R, Kawai S, Masuda G, Nakazawa S, Marchand RP. 2015. Humans frequently exposed to a range of non-human primate malaria parasite species through the bites of Anopheles dirus mosquitoes in South-central Vietnam. Parasit Vectors 8: 376.

Maier AG, Duraisingh MT, Reeder JC, Patel SS, Kazura JW, Zimmerman PA, Cowman AF. 2003. Plasmodium falciparum erythrocyte invasion through glycophorin $\mathrm{C}$ and selection for Gerbich negativity in human populations. Nat Med 9: 87-92.

Marrelli MT, Branquinho MS, Hoffmann EH, Taipe-Lagos CB, Natal D, Kloetzel JK. 1998. Correlation between positive serology for Plasmodium vivax-like/Plasmodium simiovale malaria parasites in the human and anopheline populations in the State of Acre, Brazil. Trans $R$ Soc Trop Med Hyg 92: 149-151.

Martin MJ, Rayner JC, Gagneux P, Barnwell JW, Varki A. 2005. Evolution of human-chimpanzee differences in malaria susceptibility: Relationship to human genetic loss of $\mathrm{N}$-glycolylneuraminic acid. Proc Natl Acad Sci 102: 12819-12824.

Mayer DC, Cofie J, Jiang L, Hartl DL, Tracy E, Kabat J, Mendoza LH, Miller LH. 2009. Glycophorin B is the erythrocyte receptor of Plasmodium falciparum erythrocyte-binding ligand, EBL-1. Proc Natl Acad Sci 106: $5348-5352$.

Ménard D, Barnadas C, Bouchier C, Henry-Halldin C, Gray LR, Ratsimbasoa A, Thonier V, Carod JF, Domarle O, Colin Y, Locatelli S, et al. 2010a. Origin of the human malaria parasite Plasmodium falciparum in gorillas. $\mathrm{Na}$ ture 467: 420-425.

Ménard D, Barnadas C, Bouchier C, Henry-Halldin C, Gray LR, Ratsimbasoa A, Thonier V, Carod JF, Domarle O, Colin Y, et al. 2010b. Plasmodium vivax clinical malaria is commonly observed in Duffy-negative Malagasy people. Proc Natl Acad Sci 107: 5967-5971.

Ménard D, Chan ER, Benedet C, Ratsimbasoa A, Kim S, Chim P, Do C, Witkowski B, Durand R, Thellier M, et al. 2013. Whole genome sequencing of field isolates reveals a common duplication of the Duffy binding protein gene in Malagasy Plasmodium vivax strains. PLoS Negl Trop Dis 7: e2489.
Mensah-Brown HE, Amoako N, Abugri J, Stewart LB, Agongo G, Dickson EK, Ofori MF, Stoute JA, Conway DJ, Awandare GA. 2015. Analysis of erythrocyte invasion mechanisms of Plasmodium falciparum clinical isolates across 3 malaria-endemic areas in Ghana. J Infect Dis 212: $1288-1297$.

Miller LH, Mason SJ, Dvorak JA, McGinniss MH, Rothman IK. 1975. Erythrocyte receptors for (Plasmodium knowlesi) malaria: Duffy blood group determinants. Science 189: $561-563$.

Moon RW, Hall J, Rangkuti F, Ho YS, Almond N, Mitchell GH, Pain A, Holder AA, Blackman MJ. 2013. Adaptation of the genetically tractable malaria pathogen Plasmodium knowlesi to continuous culture in human erythrocytes. Proc Natl Acad Sci 110: 531-536.

Moraes Barros RR, Straimer J, Sa JM, Salzman RE, Melendez-Muniz VA, Mu J, Fidock DA, Wellems TE. 2014. Editing the Plasmodium vivax genome, using zinc-finger nucleases. J Infect Dis 211: 125-129.

Moyes CL, Henry AJ, Golding N, Huang Z, Singh B, Baird JK, Newton PN, Huffman M, Duda KA, Drakeley CJ, et al. 2014. Defining the geographical range of the Plasmodium knowlesi reservoir. PLoS Negl Trop Dis 8: e2780.

Muchmore EA, Diaz S, Varki A. 1998. A structural difference between the cell surfaces of humans and the great apes. Am J Phys Anthropol 107: 187-198.

Mueller I, Zimmerman PA, Reeder JC. 2007. Plasmodium malariae and Plasmodium ovale - The "bashful" malaria parasites. Trends Parasitol 23: 278-283.

Mueller I, Galinski MR, Baird JK, Carlton JM, Kochar DK, Alonso PL, del Portillo HA. 2009. Key gaps in the knowledge of Plasmodium vivax, a neglected human malaria parasite. Lancet Infect Dis 9: 555-566.

Neafsey DE, Galinsky K, Jiang RH, Young L, Sykes SM, Saif S, Gujja S, Goldberg JM, Young S, Zeng Q, et al. 2012. The malaria parasite Plasmodium vivax exhibits greater genetic diversity than Plasmodium falciparum. Nature 44: 1046-1050.

Nery S, Deans AM, Mosobo M, Marsh K, Rowe JA, Conway DJ. 2006. Expression of Plasmodium falciparum genes involved in erythrocyte invasion varies among isolates cultured directly from patients. Mol Biochem Parasitol 149: 208-215.

Ollomo B, Durand P, Prugnolle F, Douzery E, Arnathau C, Nkoghe D, Leroy E, Renaud. 2009. A new malaria agent in African hominids. PLoS Pathog 5: e1000446.

Orlandi PA, Klotz FW, Haynes JD. 1992. A malaria invasion receptor, the 175-kilodalton erythrocyte binding antigen of Plasmodium falciparum recognizes the terminal Neu5Ac $(\alpha 2-3)$ Gal- sequences of glycophorin A. J Cell Biol 116: 901-909.

Otto TD, Rayner JC, Böhme U, Pain A, Spottiswoode N, Sanders M, Quail M, Ollomo B, Renaud F, Thomas AW, et al. 2014. Genome sequencing of chimpanzee malaria parasites reveals possible pathways of adaptation to human hosts. Nat Commun 5: 4754.

Pandey AK, Reddy KS, Sahar T, Gupta S, Singh H, Reddy EJ, Asad M, Siddiqui FA, Gupta P, Singh B, et al. 2013. Identification of a potent combination of key Plasmodium falciparum merozoite antigens that elicit strain-transcending parasite-neutralizing antibodies. Infect Immun 81: $441-451$. 
Patel SD, Ahouidi AD, Bei AK, Dieye TN, Mboup S, Harri son SC, Duraisingh MT. 2013. Plasmodium falciparum merozoite surface antigen, PfRH5, elicits detectable levels of invasion-inhibiting antibodies in humans. J Infect Dis 208: 1679-1687.

Paul AS, Egan ES, Duraisingh MT. 2015. Host-parasite interactions that guide red blood cell invasion by malaria parasites. Curr Opin Hematol 22: 220-226.

Paupy C, Makanga B, Ollomo B, Rahola N, Durand P, Magnus J, Willaume E, Renaud F, Rontenille D, Prugnolle F. 2013. Anopheles moucheti and Anopheles vinckei are candidate vectors of ape Plasmodium parasites, including Plasmodium praefalciparum in Gabon. PLOS ONE 8: e57294.

Persson KE, McCallum FJ, Reiling L, Lister NA, Stubbs J, Cowman AF, Marsh K, Beeson JG. 2008. Variation in use of erythrocyte invasion pathways by Plasmodium falciparum mediates evasion of human inhibitory antibodies. J Clin Invest 118: 342-351.

Pinheiro MM, Ahmed MA, Millar SB, Sanderson T, Otto TD, Lu WC, Krishna S, Rayner JC, Cox-Singh J. 2015. Plasmodium knowlesi genome sequences from clinical isolates reveal extensive genomic dimorphism. PLoS ONE 10: $\mathrm{e} 0121303$.

Prugnolle F, Durand P, Neel C, Ollomo B, Ayala FJ, Arnathau C, Etienne L, Mpoudi-Ngole E, Nkoghe D, Leroy E, et al. 2010. African great apes are natural hosts of multiple related malaria species, including Plasmodium falciparum. Proc Natl Acad Sci 107: 1458-1463.

Prugnolle F, Rougeron V, Becquart P, Berry A, Makanga B, Rahola N, Arnathau C, Ngoubangoye B, Ménard S, Willaume E, et al. 2013. Diversity, host switching and evolution of Plasmodium vivax infecting African great apes. Proc Natl Acad Sci 110: 8123-8128.

Qari SH, Goldman IF, Povoa MM, Oliveira S, Alpers MP, Lal AA. 1991. Wide distribution of the variant form of the human malaria parasite Plasmodium vivax. J Biol Chem 266: $16297-16300$.

Qari SH, Goldman IF, Povoa MM, di Santi S, Alpers MP, Lal AA. 1992. Polymorphism in the circumsporozoite protein of the human malaria parasite Plasmodium vivax. Mol Biochem Parasitol 55: 105-113.

Qari SH, Shi YP, Goldman IF, Udhayakumar V, Alpers MP, Collins WE, Lal AA. 1993. Identification of Plasmodium vivax-like human malaria parasite. Lancet 341: 780783.

Rayner JC. 2015. Plasmodium malariae malaria: From monkey to man? EBioMedicine 2: 1023-1024.

Rayner JC, Liu W, Peeters M, Sharp PM, Hahn BH. 2011. A plethora of Plasmodium species in wild apes: A source of human infection? Trends Parasitol 27: 222-229.

Reddy KS, Pandey AK, Singh H, Sahar T, Emmanuel A, Chitnis CE, Chauhan VS, Gaur D. 2014. Bacterially expressed full-length recombinant Plasmodium falciparum RH5 protein binds erythrocytes and elicits potent straintranscending parasite-neutralizing antibodies. Infect Immun 82: $152-164$

Reed MB, Caruana SR, Batchelor AH, Thompson JK, Crabb BS, Cowman AF. 2000. Targeted disruption of an erythrocyte binding antigen in Plasmodium falciparum is associated with a switch toward a sialic acid-independent pathway of invasion. Proc Natl Acad Sci 97: 7509-7514.
Reiling L, Richards JS, Fowkes FJ, Barry AE, Triglia T, Chokejindachai W, Michon P, Tavul L, Siba PM, Cowman AF, et al. 2010. Target of protective immunity against Plasmodium falciparum malaria. J Immunol 185: 6157-6167.

Reiling L, Richards JS, Fowkes FJ, Wilson DW, Chokejindachai W, Barry AE, Tham WH, Stubbs J, Langer C, Donelson J, et al. 2012. The Plasmodium falciparum erythrocyte invasion ligand Pfrh4 as a target of functional and protective human antibodies against malaria. PLoS ONE 7: e45253.

Reyes-Sandoval A. 2013. Plasmodium vivax malaria vaccines: Why are we where we are? Hum Vaccin Immunother 9: $2558-2565$.

Rich SM, Leendertz FH, Xu G, LeBreton M, Djoko CF, Aminake MN, Takang EE, Diffo JL, Pike BL, Rosenthal BM, et al. 2009. The origin of malignant malaria. Proc Natl Acad Sci 106: 14902-14907.

Rosenberg R, Wirtz RA, Lanar DE, Sattabongkot J, Hall T, Waters AP, Prasittisuk C. 1989. Circumsporozoite protein heterogeneity in the human malaria parasite Plasmodium vivax. Science 245: 973-976.

Rubio JM, Benito A, Roche J, Berzosa PJ, García ML, Micó M, Edú M, Alvar J. 1999. Semi-nested, multiplex polymerase chain reaction for detection of human malaria parasites and evidence of Plasmodium vivax infection in Equatorial Guinea. Am J Trop Med Hyg 60: 183-187.

Russell B, Suwanarusk R, Malleret B, Costa FT, Snounou G, Kevin Baird J, Nosten F, Rénia L. 2012. Human ex vivo studies on asexual Plasmodium vivax: The best way forward. Int J Parasitol 42: 1063-1070.

* Singh S, Chitnis CE. 2016. Molecular signaling involved in entry and exit of malaria parasites from host erythrocytes. Cold Spring Harb Perspect Med doi: 10.1101/cshper spect.a026815.

Singh B, Daneshvar C. 2013. Human infections and detection of Plasmodium knowlesi. Clin Microbiol Rev 26: $165-184$.

Singh B, Sung LK, Matusop A, Radhakrishnan A, Shamsul SS, Cox-Singh J, Thomas A, Conway DJ. 2004. A large focus of naturally acquired Plasmodium knowlesi infections in human beings. Lancet 363: 1017-1024.

Singh AP, Ozwara H, Kocken CH, Puri SK, Thomas AW, Chitnis CE. 2005. Targeted deletion of Plasmodium knowlesi Duffy binding protein confirms its role in junction formation during invasion. Mol Microbiol 55: 19251934.

Snounou G, Viriyakosol S, Zhu XP, Jarra W, Pinheiro L, do Rosario VE, Thaithong S, Brown KN. 1993. High sensitivity of detection of human malaria parasites by the use of nested polymerase chain reaction. Mol Biochem Parasitol 61: 315-320.

Stubbs J, Simpson KM, Triglia T, Plouffe D, Tonkin CJ, Duraisingh MT, Maier AG, Winzeler EA, Cowman AF. 2005. Molecular mechanism for switching of $P$. falciparum invasion pathways into human erythrocytes. Science 309: 1384-1387.

Sundararaman SA, Liu W, Keele BF, Learn GH, Bittinger K, Mouacha F, Ahuka-Mundeke S, Manske M, Sherrill-Mix S, Li Y, et al. 2013. Plasmodium falciparum-like parasites infecting wild apes in southern Cameroon do not represent a recurrent source of human malaria. Proc Natl Acad Sci 110: 7020-7025. 
C. Lim et al.

Sutherland CJ, Tanomsing N, Nolder D, Oguike M, Jennison C, Pukrittayakamee S, Dolecek C, Hien TT, do Rosário VE, Arez AP, et al. 2010. Two nonrecombining sympatric forms of the human malaria parasite Plasmodium ovale occur globally. J Infect Dis 201: 1544-1550.

Ta TH, Hisam S, Lanza M, Jiram Al, Ismail N, Rubio JM. 2014. First case of a naturally acquired human infection with Plasmodium cynomolgi. Malaria J 13: 1-7.

Tachibana M, Tsuboi T, Kaneko O, Khuntirat B, Torii M. 2002. Two types of Plasmodium ovale defined by SSU rRNA have distinct sequences for ookinete surface proteins. Mol Biochem Parasitol 122: 223-226.

Taylor LH, Latham SM, Woolhouse ME. 2001. Risk factors for human disease emergence. Philos Trans R Soc B Biol Sci 356: 983-989.

Tham WH, Healer J, Cowman AF. 2012. Erythrocyte and reticulocyte binding-like proteins of Plasmodium falciparum. Trends Parasitol 28: 23-30.

Triglia T, Duraisingh MT, Good RT, Cowman AF. 2005. Reticulocyte-binding protein homologue 1 is required for sialic acid-dependent invasion into human erythrocytes by Plasmodium falciparum. Mol Microbiol 55: 162-174.

Udhayakumar V, Qari SH, Patterson P, Collins WE, Lal AA. 1994. Monoclonal antibodies to the circumsporozoite protein repeats of a Plasmodium vivax-like human malaria parasite and Plasmodium simiovale. Infect Immun 62: 2098-2100.

Valencia SH, Rodríguez DC, Acero DL, Ocampo V, ArévaloHerrera M. 2011. Platform for Plasmodium vivax vaccine discovery and development. Mem Inst Oswaldo Cruz 106: 179-192.

van Rooyen CE, Pile GR. 1935. Observations on infection by Plasmodium knowlesi (ape malaria) in the treatment of general paralysis of the insane. $\mathrm{Br}$ Med J 2: 662-666.
Vythilingam I. 2010. Plasmodium knowlesi in humans: A review on the role of its vectors in Malaysia. Trop Biomed 27: $1-12$.

Wanaguru M, Crosnier C, Johnson S, Rayner JC, Wright GJ. 2013. Biochemical analysis of the Plasmodium falciparum erythrocyte-binding antigen-175 (EBA175)-glycophorin-A interaction: Implications for vaccine design. $J$ Biol Chem 288: 32106-32117.

Wertheimer SP, Barnwell JW. 1989. Plasmodium vivax interaction with the human Duffy blood group glycoprotein: Identification of a parasite receptor-like protein. Exp Parasitol 69: 340-350.

White NJ, Pukrittayakamee S, Hien TT, Faiz MA, Mokuolu OA, Dondorp AM. 2014. Malaria. Lancet 383: 723-735.

Williams AR, Douglas AD, Miura K, Illingworth JJ, Choudhary P, Murungi LM, Furze JM, Diouf A, Miotto O, Crosnier C, et al. 2012. Enhancing blockade of Plasmodium falciparum erythrocyte invasion: Assessing combinations of antibodies against PfRH5 and other merozoite antigens. PLoS Pathog 8: e1002991.

Win TT, Jalloh A, Tantular IS, Tsuboi T, Ferreira MU, Kimura M, Kawamoto F. 2004. Molecular analysis of Plasmodium ovale variants. Emerg Infect Dis 10: 1235-1240.

Woldearegai TG, Kremsner PG, Kun JFJ, Mordmuller B. 2013. Plasmodium vivax malaria in Duffy-negative individuals from Ethiopia. Trans R Soc Trop Med Hyg 107: $328-331$.

WHO. 2015. World malaria report 2015. World Health Organization, Geneva, pp. 1-280.

Wright GJ, Rayner JC. 2014. Plasmodium falciparum erythrocyte invasion: Combining function with immune evasion. PLoS Pathog 10: ve1003943.

Young MD, Eyles DE, Burgess RW, Jeffery GM. 1955. Experimental testing of the immunity of Negroes to Plasmodium vivax. J Parasitol 41: 315-318. 


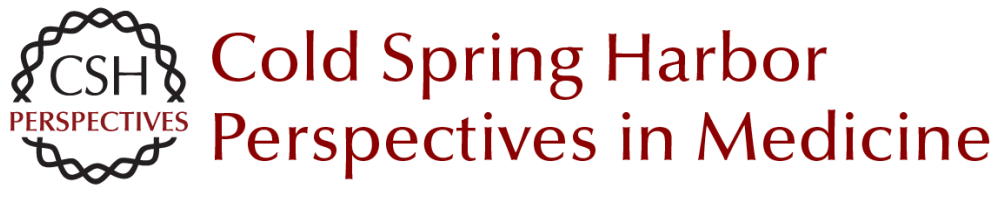

\title{
Host Cell Tropism and Adaptation of Blood-Stage Malaria Parasites: Challenges for Malaria Elimination
}

\author{
Caeul Lim, Selasi Dankwa, Aditya S. Paul and Manoj T. Duraisingh
}

Cold Spring Harb Perspect Med 2017; doi: 10.1101/cshperspect.a025494 originally published online February 17, 2017

\section{Subject Collection Malaria: Biology in the Era of Eradication}

Modern Vector Control

Neil F. Lobo, Nicole L. Achee, John Greico, et al.

Anopheline Reproductive Biology: Impacts on Vectorial Capacity and Potential Avenues for Malaria Control

Sara N. Mitchell and Flaminia Catteruccia

Current and Future Prospects for Preventing

Malaria Transmission via the Use of Insecticides Hilary Ranson

Molecular Signaling Involved in Entry and Exit of Malaria Parasites from Host Erythrocytes Shailja Singh and Chetan E. Chitnis

Vaccines to Accelerate Malaria Elimination and Eventual Eradication Julie Healer, Alan F. Cowman, David C. Kaslow, et al.

Immune Responses in Malaria Carole A. Long and Fidel Zavala

Antimalarial Drug Resistance: A Threat to Malaria Elimination Didier Menard and Arjen Dondorp

Malaria during Pregnancy Michal Fried and Patrick E. Duffy
Malaria Pathogenesis

Danny A. Milner, Jr.

Determinants of Malaria Transmission at the Population Level

Teun Bousema and Chris Drakeley

Host Cell Tropism and Adaptation of Blood-Stage

Malaria Parasites: Challenges for Malaria

Elimination

Caeul Lim, Selasi Dankwa, Aditya S. Paul, et al.

Malaria Transmission and Prospects for Malaria

Eradication: The Role of the Environment Marcia C. Castro

The Biology of Plasmodium vivax John H. Adams and Ivo Mueller

Malaria Genomics in the Era of Eradication Daniel E. Neafsey and Sarah K. Volkman

Malaria Epigenetics Alfred Cortés and Kirk W. Deitsch

Malaria Parasite Liver Infection and Exoerythrocytic Biology Ashley M. Vaughan and Stefan H.I. Kappe

For additional articles in this collection, see http://perspectivesinmedicine.cshlp.org/cgi/collection/ 